Historia Slavorum Occidentis

2018, nr 4 (19)

ISSN 2084-1213

DOI: $10.15804 /$ hso 180407

\title{
Karol F. Sabath. Portret listami pisany, red. Wojciech Grajewski, Towarzystwo Miłośników Brennej i Górek „Jodła”, \\ Brenna 2017, ss. 252
}

W dziejach polskiej prasy ważne miejsce zajmuje „Gwiazdka Cieszyńska”, ukazująca się w latach 1851-1939. Przez ponad trzy dekady pod redakcją Pawła Stalmacha (pełnił tę funkcję do 1887 r.) była de facto organem polskiego ruchu narodowego na Śląsku Cieszyńskim, a od lat osiemdziesiątych XIX w. jego katolickiego skrzydła, którego polityczną reprezentację przez długie lata stanowił Związek Śląskich Katolików.

Nie ulega wątpliwości, że redaktorzy „Gwiazdki Cieszyńskiej” byli postaciami znaczącymi co najmniej w skali regionu. Najwięcej miejsca w literaturze naukowej poświęcono Pawłowi Stalmachowi i księdzu Józefowi Londzinowi, zaliczających się do grona liderów polskiego ruchu narodowego na Śląsku Cieszyńskim ${ }^{1}$. Pozostali doczekali się skromnych biogramów w rozmaitych kompendiach biograficznych albo - jak chociażby Wawrzyniec Grylewicz - wciąż czekają na swoich biografów².

Ostatnim przedwojennym redaktorem „Gwiazdki Cieszyńskiej” był Karol Ferdynand Sabath (1902-1942). Trudno zestawiać go z „olbrzymami” pokroju Stalmacha

\footnotetext{
1 Jednocześnie obaj nie doczekali się wyczerpujących monografii. Pomijając biogramy w różnego rodzaju leksykonach o Stalmachu zob. E. Grim, Pawet Stalmach: jego życie i działalność $w$ świetle prawdy, Cieszyn 1910; I. Homola-Skąpska, Tygodnik Cieszyński i Gwiazdka Cieszyńska pod redakcja Pawła Stalmacha 1848-1887, Katowice-Kraków 1968; E. Buława, Pierwsi szermierze ruchu narodowego na Śląsku Cieszyńskim, Cieszyn 1997, z kolei o Londzinie: Ks. Józef Londzin (1862-1929). Kapłan, działacz patriotyczny i społeczny, red. K. Nowak, Bielsko-Biała 2002.

2 Zestawienie redaktorów do 1920 r.: S. Zahradnik, Czasopiśmiennictwo w języku polskim na terenach Czechosłowacji w latach 1848-1938, Opole 1989, s. 87. Zestawienie biogramów zob.: Elektroniczny Słownik Biograficzny Śląska Cieszyńskiego, http://slownik.kc-cieszyn.pl/index. php/content,592/ [dostęp z dnia 16 IV 2018].
} 
czy Londzina, ale pamiętać trzeba, że karierę Sabatha brutalnie przerwała druga wojna światowa. W 1941 r. został aresztowany przez Niemców, a rok później zginął straszliwą śmiercią w obozie koncentracyjnym w Mauthausen. Pod wieloma względami był postacią wyjątkową - przyszedł na świat jako syn arcyksiążęcego gajowego, wyrastał w domu, gdzie podstawowym językiem był niemieckim, a jednak pozostał oddany polskości aż do tragicznego końca. Niezwykle aktywny działacz społeczny, erudyta-samouk, już w wieku dwudziestu lat został administratorem „Gwiazdki Cieszyńskiej”.

W 2017 r. nakładem Towarzystwa Miłośników Brennej i Górek „Jodła” ukazała się książka poświęcona tej zasłużonej postaci, zatytułowana Karol F. Sabath. Portret listami pisany pod redakcją Wojciecha Grajewskiego, absolwenta Uniwersytetu Jagiellońskiego i doktoranta na Uniwersytecie Techniczno-Humanistycznym im. Jana Długosza w Częstochowie, mającego w swoim dorobku naukowym m.in. monografię dziejów Brennej do $1848 \mathrm{r}^{3}$

Na recenzowaną książkę składa się osiem tekstów, nie licząc wstępu pióra Doroty Greń-Grajewskiej i W. Grajewskiego. Pierwszym jest edycja listów Karola Ferdynanda Sabatha do jego narzeczonej Ewy Hellerówy (para pobrała się w 1927 r.), przygotowana przez ich wnuczkę, Beatę Sabath. Kiedy uświadomimy sobie, że w historiografii (nie tylko) regionalnej większość biogramów opartych jest głównie na oficjalnych dokumentach, informacjach prasowych i sporadycznych wzmiankach pamiętnikarskich, tym bardziej należy docenić znaczenie tego rodzaju źródeł.

Drugim tekstem są wspomnienia o Sabacie jego wspólpracownika Franciszka Halskiego-Hessa (1910-1996), drukarza i działacza społecznego. Halski-Hess spisał je w 1986 r. i przekazał rodzinie ostatniego redaktora „Gwiazdki Cieszyńskiej”.

Trzecim jest obszerny artykuł W. Grajewskiego poświęcony tytułowemu bohaterowi - Ostatni redaktor „Gwiazdki Cieszyńskiej” - szkic biograficzny. Autor opiera się głównie na materiałach rodzinnych znajdujących się w posiadaniu potomków Sabatha i skrupulatnie przebadanej prasie, przy okazji prostując nieprecyzyjne informacje pojawiające się w literaturze przedmiotu. Sabath był nie tylko redaktorem „Gwiazdki Cieszyńskiej”, ale też aktywnym działaczem społecznym, bodaj najbardziej zasłużonym w dziejach Brennej. Tekst W. Grajewskiego czyta się wyjątkowo przyjemnie - z jednej strony czuć fascynację opisywaną postacią, z drugiej widać ostrożność i rozwagę w formułowaniu hipotez.

3 W. Grajewski, Brenna. Dzieje góralskiej wsi Śląska Cieszyńskiego, t. 1, Brenna 2014. 
Całość tomu zamykają przedruki trzech krótkich artykułów Sabatha z lat 1926-1937 oraz tekstu poety ludowego Jerzego Probosza (1901-1942), który w 1929 r. na łamach „Gwiazdki Cieszyńskiej” opisywał swoje refleksje po wizycie w Brennej.

Publikacja jest bogato ilustrowana i starannie zredagowana. Udało mi się wychwycić ledwie jedną literówkę (s. 211 przypis 79; ma być „rodziny”, a nie „rodzinny"). Zastanawiałem się nad kompozycją pracy, czy nie lepiej było rozpocząć od artykułu W. Grajewskiego, a później zamieścić źródła (listy, wspomnienia F. Halskiego-Hessa, itp.), ale przyjęte rozwiązanie jest chyba atrakcyjniejsze z punktu widzenia czytelnika. Najpierw poznajemy Karola Ferdynanda Sabatha przez pryzmat jego korespondencji z narzeczoną (później żoną), a następnie relacji bliskiego współpracownika - przez co jawi się nam jako postać z krwi i kości, a nie kolejny szablonowy „zasłużony człowiek”. A dopiero wtedy możemy oddać się lekturze jego szczegółowego życiorysu.

Recenzowane opracowanie wypełnia pewną lukę w regionalnej historiografii, dając szczegółowe omówienie działalności Karola Ferdynanda Sabatha i jako działacza społecznego, i jako redaktora „Gwiazdki Cieszyńskiej”. Powinni na nie zwrócić uwagę również badacze, którzy nie zajmują się dziejami Śląska Cieszyńskiego. Szczególnie ciekawe w kontekście drogi życiowej Sabatha są jego wybory narodowe - może pełnić niemal funkcję swoistego papierka lakmusowego, pozwalającego weryfikować różne twierdzenia na temat kształtowania się i rozwoju tożsamości narodowej w środkowej Europie.

dr Michael Morys-Twarowski

Polskie Towarzystwo Historyczne

Oddział w Cieszynie

ul. Mennicza 46

43-400 Cieszyn

morys-twarowski@wp.pl 